\title{
REVIEW
}

\section{On type 1 diabetes mellitus pathogenesis}

\author{
Stavroula A Paschou, Nektaria Papadopoulou-Marketou, George P Chrousos and Christina Kanaka-Gantenbein \\ Division of Endocrinology, Metabolism and Diabetes, First Department of Pediatrics, 'Aghia Sophia' Children's Hospital, Medical School, National and \\ Kapodistrian University of Athens, Athens, Greece
}

Correspondence should be addressed to C Kanaka-Gantenbein: chriskan@med.uoa.gr

\begin{abstract}
Type 1 diabetes mellitus (T1DM) results from the autoimmune destruction of $\beta$ cells of the endocrine pancreas. Pathogenesis of T1DM is different from that of type 2 diabetes mellitus, where both insulin resistance and reduced secretion of insulin by the $\beta$ cells play a synergistic role. We will present genetic, environmental and immunologic factors that destroy $\beta$ cells of the endocrine pancreas and lead to insulin deficiency. The process of autoimmune destruction takes place in genetically susceptible individuals under the triggering effect of one or more environmental factors and usually progresses over a period of many months to years, during which period patients are asymptomatic and euglycemic, but positive for relevant autoantibodies. Symptomatic hyperglycemia and frank diabetes occur after a long latency period, which reflects the large percentage of $\beta$ cells that need to be destroyed before overt diabetes become evident.
\end{abstract}

\section{Key Words}

- type 1 diabetes

- pathogenesis

- genetics

- autoimmunity

- microbiota

\section{Introduction}

Type 1 diabetes mellitus (T1DM) represents only around $10 \%$ of the diabetes cases worldwide, but occurs with increasing incidence much earlier in life. T1DM results from the autoimmune destruction of $\beta$ cells of the endocrine pancreas. A small percentage of affected patients $(<10 \%)$ are classified as type $1 \mathrm{~B}$, with no evidence of autoimmunity and the pathogenesis in these cases is considered idiopathic $(1,2)$. The aim of this comprehensive review is to present updated information on the pathogenesis of T1DM. We will present genetic, environmental and immunologic factors (Table 1) that eventually destroy $\beta$ cells of the endocrine pancreas and lead to insulin deficiency.

\section{Genetic factors}

Type 1 diabetes is usually present in individuals without a family history. Only $10-15 \%$ of the patients have a first- or second-degree relative with the disease. However, the lifetime risk for developing T1DM is significantly increased in relatives of patients, as about $6 \%$ of children, $5 \%$ of siblings and $50 \%$ of monozygotic twins present

$$
\begin{array}{lr}
\text { http://www.endocrineconnections.org } & \odot 2018 \text { The authors } \\
\text { https://doi.org/10.1530/EC-17-0347 } & \text { Published by Bioscientifica Ltd }
\end{array}
$$

the disease compared to $0.4 \%$ prevalence of the general population $(3,4)$. More than 50 T1DM genetic risk loci have been identified by genome-wide association studies and meta-analyses (5). The main genes predisposing to T1DM are within the major histocompatibility complex (MHC) region, often called HLA (human leucocyte antigen) and located on chromosome 6. HLA complex polymorphic alleles are responsible for $40-50 \%$ of the genetic risk of T1DM development. The insulin gene (Ins-VNTR, IDDM 2) polymorphisms on chromosome 11 and the cytotoxic T lymphocyte-associated antigen- 4 gene (CTLA-4) on chromosome 2 follow, as these are responsible for $15 \%$ of the genetic predisposition. Many other different genetic loci have been found to contribute in a lesser degree to the genetic susceptibility for T1DM alone or in combination with other autoimmune diseases $(5,6)$. Some of them will be briefly presented.

\section{MHC}

MHC is a group of closely related genetic loci encoding molecules expressed on the surface of immune or other cells and limiting the specificity of $\mathrm{T}$ lymphocytes to

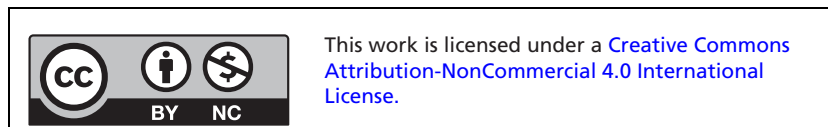


Table 1 Contributing factors in type 1 diabetes mellitus pathogenesis.

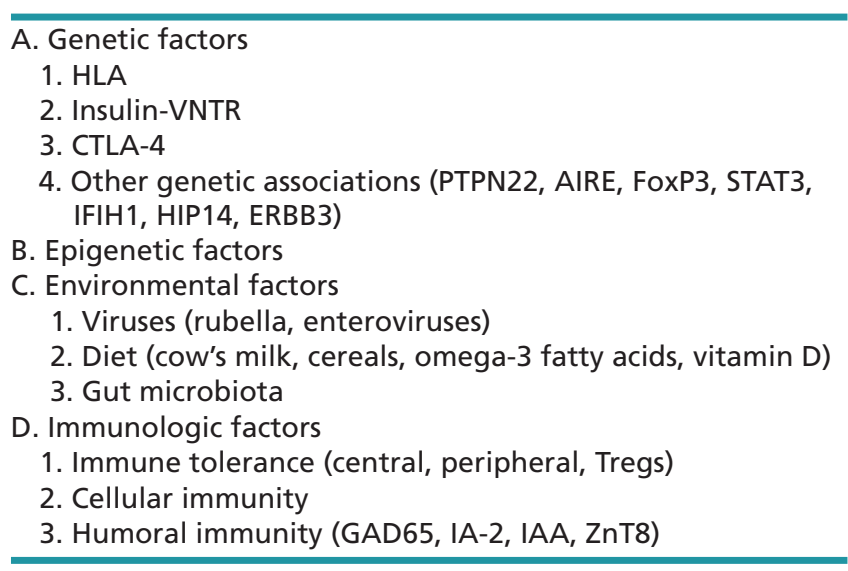

recognize antigens. Based on the functional specificity of their products, HLA gene loci are distinguished into two classes. Class I HLA molecules are associated with antigens that are recognized by the receptor of cytotoxic $\mathrm{T}$ lymphocytes (CD8+), which eventually destroy the antigenic target and are expressed by most cells. Class II HLA molecules are essential for the recognition of antigens by $\mathrm{T}$ helper lymphocytes (CD4+), which initiate the immune response and promote cellular co-operation and are expressed only by immune cells $(7,8)$.

In T1DM, associations with specific HLA alleles or haplotypes refer to class II region, as this is the case for the majority of autoimmune diseases. The ability of class II molecules to present antigens is dependent on their alpha- and beta-chain amino acid composition. Substitutions at one or two critical sites can significantly increase or decrease the binding capacity of the relevant autoantigens. Particularly, more than $90 \%$ of the patients with T1DM have either HLA-DR3, DQB1*0201 (also referred as DR3-DQ2) or HLA-DR4, DQB1*0302 (also referred as DR4-DQ8) haplotypes compared to $40 \%$ of the healthy individuals. In addition, about $30 \%$ of the patients have both haplotypes (DR3/4 heterozygotes) $(9,10)$. On the other hand, the presence of some DR4 alleles, such as DRB $1{ }^{*} 0403$ and DPB $1{ }^{*} 0402$, reduces the risk of T1DM development even in the presence of DQB1*0302 high-risk allele. In addition, the HLA allele DQB1*0602 provides protection against T1DM development. This allele is present in approximately $20 \%$ of the general US population but only in $1 \%$ of the children who have developed T1DM $(1,11,12,13)$.

Autoimmune polyendocrine syndrome 2 (APS 2) presents in association with the HLA II genes. It is more frequent in women and manifests in adulthood.
Addison's disease is the prevailing disorder with up to $70 \%$ prevalence, and it is often combined with type 1 diabetes (up to 50\% prevalence in patients with the syndrome). Autoimmune thyroid disease follows, while other autoimmune diseases, such as vitiligo, alopecia, gonadal failure and celiac disease, may manifest, but less frequently (14).

\section{Insulin-VNTR}

Polymorphisms in the region of the insulin gene promoter are estimated to account for about $10 \%$ of the genetic predisposition for T1DM. This region is located on the short arm of chromosome 11 and is close to the gene encoding for proinsulin. This polymorphic site consists of a variable numbers of tandem repeats (VNTRs). It is present in two common classes: the small class (26-63 repeats, type I) or the big class (140-243 repeats, type III) (15). This genetic locus does not itself encode a protein, but plays an important role in initiating the transcription process of insulin. Type III is present in approximately $30 \%$ of the general population and provides protection from T1DM regardless of the individual HLA haplotypes. It is believed that the presence of the big class allele facilitates transcription and epithelial expression, therefore the autoantigen presentation of insulin in the fetal thymus. Thus, it is protective by promoting the negative selection and deletion of $\mathrm{T}$ lymphocytes reactive to insulin that contribute to the autoimmune destruction of $\beta$ cells $(15,16)$.

\section{CTLA-4}

The CTLA-4 gene (cytotoxic T lymphocyte antigen-4) is located on the long arm of chromosome 2 (2q33) and has also been associated with T1DM. It has a suppressive role, a role of transmitting negative signal and inducing anergy in activated $\mathrm{T}$ lymphocytes (17). Identification of the antigen by the naive $\mathrm{T}$ lymphocyte is achieved through a triple complex consisting of the antigen, the HLA molecule of the antigen presenting cell (APC) and the T lymphocyte antigen receptor $(\mathrm{Ag}+\mathrm{HLA}+\mathrm{TCR})$. However, this complex recognition is not capable itself of stimulating the naive $\mathrm{T}$ lymphocyte for proliferation and differentiation into an active $\mathrm{T}$ lymphocyte, but costimulatory molecules are necessary. Such molecules are the B7.1 (CD80) and B7.2 (CD86) glycoproteins on the APCs and the CD28 receptor, a member of the immunoglobulin superfamily, on $\mathrm{T}$ lymphocytes. In the absence of costimulatory molecules, the $\mathrm{T}$ lymphocyte is not stimulated and

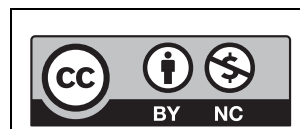

This work is licensed under a Creative Commons Attribution-NonCommercial 4.0 International License. 
switches to the anergy state. The active $\mathrm{T}$ lymphocyte further expresses the CTLA-4 receptor, which resembles the sequence of $\mathrm{CD} 28$, but has 20 -fold greater affinity for B7 glycoproteins. The CTLA-4 receptor, when linked to one of the B7 (CD80/CD86) molecules of the APC, transmits negative messages to $\mathrm{T}$ lymphocyte, limiting in this way the production of IL-2 and the proliferation of stimulated cells. Therefore, excessive stimulation and proliferation of $\mathrm{T}$ lymphocytes are avoided (8). Polymorphisms of CTLA-4 have been associated with T1DM and with other autoimmune diseases. These polymorphisms lead to decreased intracellular expression of the protein; therefore, the inhibition of excessive stimulation and proliferation of $\mathrm{T}$ lymphocytes is not inhibited resulting in uncontrolled progression of immune response and autoimmune imbalance $(17,18)$.

\section{Other genetic associations}

\section{PTPN22}

Recent studies have shown associations between C1858T (Arg620Trp) polymorphism of the PTPN22 (protein tyrosine phosphatase non-receptor type 22) gene and T1DM, as well as other autoimmune disorders. The PTPN22 gene encodes the specific lymphoid tyrosyl phosphatase known as LYP. LYP phosphatase is a very potent inhibitor of the activation of naive $\mathrm{T}$ lymphocytes, preventing spontaneous T-cell activation by dephosphorylating and inactivating a kinase, named CSK. A missense mutation in the PTPN22 gene was found to be associated with various autoimmune diseases, including type 1 diabetes. This mutation decreases the binding affinity of LYP to CSK, leading to uncontrolled T-cell activation and autoimmune reaction $(19,20)$.

\section{AIRE}

Presentation of autoantigens in both the thymus and the periphery to negatively select and delete $\mathrm{T}$ lymphocytes that are highly reactive (central and peripheral immune tolerance, respectively) is a very important regulatory mechanism of autoimmunity. The AIRE protein (autoimmune regulator) is mainly expressed in the epithelial and dendritic cells of the thymus marrow. It is a transcription factor which controls the expression of many specific autopeptides (8). Patients with mutations in the AIRE gene, located on the long arm of the chromosome 21 (21q22.3), exhibit autoimmune polyendocrine syndrome 1 (APS 1), also known as APECED syndrome, which is the acronym of its main clinical manifestations,

$$
\text { http://www.endocrineconnections.org }
$$

polyendocrine autoimmunity (Addison's disease, hypoparathyroidism, T1DM), candidiasis and ectodermal dystrophy (autoimmune polyendocrinopathy candidiasis ectodermal dystrophy - APECED). The presence of T1DM in patients with AIRE mutations (less frequent of course than in APS 2) demonstrates that the expression and presentation of relevant autoantigens (insulin, GAD, IA-2) in the thymus are under the surveillance of this transcription factor $(21,22)$.

\section{FoxP3}

The gene of the transcription factor FoxP3 is located on chromosome $\mathrm{X}$ and encodes for a protein known as 'scurfin'. The congenital dysfunction of FoxP3 is manifested by an autoimmune phenotype, which in mice has been characterized as 'scurfy', usually leading to death early in life. In humans, it appears as an autoimmune polyendocrine disorder associated with chromosome $\mathrm{X}$ (IPEX syndrome) and is manifested with a milder phenotype comprising of T1DM, allergies, enteropathies and eczema (23). FoxP3 transcription factor is the hallmark of $\mathrm{T}$ regulatory lymphocytes (Tregs). The level of expression of Foxp3 in Tregs is positively associated with the $\alpha$-chain expression of the IL-2 receptor (CD25) and inversely associated with the expression of the $\alpha$-chain of the receptor for IL-7 (CD127). Tregs suppress the proliferation and secretory activity of CD4+ and CD8+ $\mathrm{T}$ cells, as well as the cytolytic activity of the latter (24).

\section{STAT3}

The two major subpopulations of CD4+ T lymphocytes, Th1 and Th2, derive from the same precursor T lymphocyte under the influence of specific cytokines within the lymph nodes. IL-12 produced by activated macrophages and dendritic cells induces Th1 differentiation by activation of the transcription factors STAT1, STAT3 and STAT4 (8). Mutations in the STAT3 transcription factor have been identified as monogenic causes of autoimmune diseases. De novo activating mutations of STAT3 are associated with an early onset spectrum of autoimmune diseases, such as T1DM and autoimmune thyroid dysfunction (25).

\section{IFIH1}

The interferon-induced helicase $\mathrm{C}$ domain 1 (IFIH1) gene is located on Chr2q24.2. This gene encodes the MDA5 (melanoma differentiation-associated protein 5) protein, a cytoplasmic sensor of viral double-stranded RNA, that 
activates a cascade of anti-viral immune responses. Rare variants of IFIH1 through a lost or reduced expression of the protein are protective against T1DM, whereas common IFIH1 single nuclear polymorphisms (SNPs) are associated with the disease $(26,27)$.

\section{HIP14}

The Huntingtin-interacting protein 14 gene is located on chromosome 12 and encodes for a palmitoyl transferase, which is involved in the metabolism and trafficking of proteins met with neurons. Knockdown of the genes in mice revealed increased apoptosis for pancreatic $\beta$ cells. On the other hand, increased expression of HIP14 was protected against apoptosis and this was in association with reduced nuclear-factor kappa B (NFkB) activity $(28,29)$.

\section{ERBB3}

The Erb-B2 receptor tyrosine kinase 3 (ERBB3) gene is located on chromosome 12 and encodes for an enzyme interacting with various receptors, but lacks intrinsic activity. ERBB3 seems to play an important role in cytokineinduced apoptosis of $\beta$ cells. Several SNPs (especially the rs2292239) have been associated with the presence of T1DM, as well as the glycemic control of patients with the disease $(5,6,7,8,9,10,11,12,13,14,15,16,17,18,19$, $20,21,22,23,24,25,26,27,28,29,30)$.

\section{Environmental factors}

Environmental factors also play an important role in the pathogenesis of T1DM. Strong evidence for this derives from the study of monozygotic twins, where occurrence of the disease in both siblings varies around 50\% and never reaches $100 \%(3,4)$. The environmental factors involved include viruses (rubella, coxsackievirus B or enteroviruses), toxins and nutrients (cow's milk, cereals). The precise effect of these factors remains unclear, but it is important to be identified, since these factors can be modified and possibly lead to prevention or treatment interventions.

\section{Viruses and vaccinations}

Viruses represent important triggers for T1DM pathogenesis and this was originally described by epidemiological observations. Children exposed during fetal life to rubella

$$
\begin{array}{lr}
\text { http://www.endocrineconnections.org } & \text { ○ } 2018 \text { The authors } \\
\text { https://doi.org/10.1530/EC-17-0347 } & \text { Published by Bioscientifica Ltd }
\end{array}
$$

have an increased incidence of T1DM, besides other autoimmune disorders, such as autoimmune thyroiditis (31). Furthermore, RNA or proteins from such viruses have been detected in the pancreas and other neighboring tissues from patients with T1DM. Enteroviruses can play an important role in the early phase of the development of T1DM through the activation of innate immunity (32). There is also a link between T1DM and the interferoninduced helicase 1 (IFIH1) gene, which encodes for the MDA5. Upon viral infection, MDA5 acts as a cytoplasmic sensor especially for coxsackieviruses $B$ and stimulates the production of molecular mediators of the innate immune response (33).

Another mechanism by which the autoimmune response can be induced by viruses is that of molecular mimicry. The hypothesis of molecular mimicry suggests that the immune response is directed against autoantigens that resemble the viruses' antigens and this results in cellular destruction $(34,35)$. In T1DM, the best studied paradigm of molecular mimicry is the P2-C protein of the Coxsackie B4 virus. There is significant similarity in the amino acid sequence between the Coxsackie B4 P2-C protein and the glutamic acid decarboxylase (GAD65) enzyme found in $\beta$ cells of the endocrine pancreas (36). Experimental studies have shown that clones from T-cell lines, that recognized both GAD65 and P2C peptides, reacted with both using different restriction elements and without cross-reaction needed (37). Of course, T-cell autoactivation after Coxsackie virus infection which leads to inflammation, tissue damage and release of islet autoantigens can additively occur (38). On the other hand, there is some experimental evidence that under certain conditions, enteroviruses can be also able to protect individuals against T1DM (39).

There was some concern that vaccinations may be related to the subsequent development of chronic autoimmune diseases, including T1DM. However, immunization of infants even with genetic predisposition (siblings of patients with T1DM) does not appear to be associated with an increased risk for development of the disease (40).

\section{Diet and gut microbiota}

The importance of diet in the development of T1DM remains controversial. In several studies, associations of early introduction in the infant's diet of cow's milk with an increased risk for the disease have been reported, supporting that infant's exposure to insulin contained in the milk is triggering the autoimmune response (41).

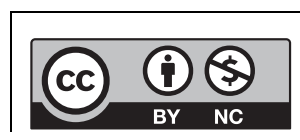

This work is licensed under a Creative Commons Attribution-NonCommercial 4.0 International License. 
In addition, earlier experimental studies mainly have demonstrated that a particular part of the albumin contained in cow's milk, known as ABBOS (17 peptide, positions 152-167), can function as a self-reactive epitope since it resembles the p69 protein found in the surface of pancreatic $\beta$ cells $(42,43)$. Early integration of cereals into the diet (44), nitrate exposure from water intake (45), inadequate intake of omega-3 fatty acids (46) and vitamin $\mathrm{D}$ deficiency $(47,48)$ have also been implicated. On the other hand, meta-analysis of observational studies (49) and vitamin D supplementation studies $(50,51)$ do not seem to confirm its protective role.

Recent data indicate that gut microbiota, the microflora of trillions of microorganisms living in the gastrointestinal tract, is involved in the pathogenesis of T1DM. Indeed, patients with T1DM exhibit differences in their gut microbiota compared to healthy controls, specifically a reduced Firmicutes vs Bacteroidetes ratio $(52,53)$. Whether the changes in the composition of the gut microbiota derive from the changes in nutrition, agricultural production and product preparation, personal hygiene and antibiotic use, especially during the first years of life, which coincide with the increased incidence of T1DM or whether they are the result of the disease itself or even its cause requires further investigation. Even the birth process seems to play a role, as suggested by the increased risk of T1DM in children born by cesarean section. Lack of contact with the vaginal microbiome of the mother and subsequent differences in their gut microbiota due to abnormal colonization may be a pathogenic mechanism and indicate the possible protective role of normal labor and vaginal delivery $(54,55)$. Anyway, the gut microbiota can affect the immune response through various pathways and further studies will elucidate host and microbiota interactions, possibly suggesting new diagnostic or therapeutic strategies for the prevention and treatment of T1DM $(52,53)$.

\section{Immunologic factors}

\section{Immune tolerance}

The human immune system faces a huge variety of antigens and its purpose is to distinguish foreign from thyself. The repertoire of specific recognition molecules is not genetically restricted and through re-organization mechanisms ends up being extremely broad. This results in antigenic receptors that are self-reactive for many tissues, including pancreatic $\beta$ cells. Potentially dangerous

$$
\text { http://www.endocrineconnections.org }
$$

immune cells during growth of $\mathrm{T}$ lymphocytes in the thymus and $\mathrm{B}$ lymphocytes in the bone marrow are negatively selected and eliminated (central tolerance). Self-reactive lymphocytes, which escape the mechanisms of central tolerance and end up in the periphery, naturally enter into processes that either neutralize or suppress them (peripheral tolerance). Disorders of these immune mechanisms can result under various autoimmune conditions (8). Mutations in the AIRE gene, but also non-genetic factors, can disturb central tolerance in thymus and lead to the development of T1DM. An interesting hypothesis is that of the implication of viral infections, which can affect human thymus. Thymic epithelial cells and thymocytes have been proved to become targets of infection with coxsackievirus B4 virus and other enteroviruses in experimental studies. Several abnormalities were then observed, including the maturation and differentiation processes of $\mathrm{T}$ cells $(56,57)$. In recent years, it has been demonstrated that the subpopulation of $\mathrm{T}$ regulatory lymphocytes (Tregs, formerly known as suppressive lymphocytes) plays an important role in the immune response network, especially for peripheral tolerance. It has been found that patients with T1DM present quantitative and qualitative deficits in Tregs, which may explain the increased (without limits) immune response, which eventually leads to the autoimmune response $(1,23,58,59)$.

\section{Cellular immunity}

The destruction of the $\beta$ cells of the endocrine pancreas in T1DM occurs most probably via apoptosis, a mechanism also known as programmed cell death, which includes a cascade of cysteine-asparaginase activations, known as caspases. Indeed, animal studies and in vitro experiments do support apoptosis as a major cell death type for $\beta$ cells; however, necrosis and necroptosis may be also important in humans $(60,61,62)$. According to one hypothesis, inflammatory reaction with high levels of the proinflammatory cytokines IL-1, TNF- $\alpha$ (tumor necrosis factor- $\alpha$ ) and INF- $\gamma$ (interferon- $\gamma$ ) is induced by the autoreactive $\mathrm{T}$ lymphocytes within the islet microenvironment. These cytokines activate the caspase cascade. Other theories suggest that apoptosis is induced directly by contact of autoreactive T lymphocytes with $\beta$ cells via the perforating system or Fas/Fas ligand interaction. Even in this case, cytokines' secretion disorder is required $(1,2,8,60,61,62)$. The subpopulation of Tregs is of great interest and their quantitative and qualitative deficits in patients with the disease are very important 
$(58,59)$. Prior to the onset of T1DM, a chronic atrophic inflammation within the islets of Langerhans is observed histologically, with the participation of $\mathrm{T}$ lymphocytes, macrophages, B lymphocytes and dendritic cells. This condition usually evolves over many months or years, when patients are asymptomatic and euglycemic. Symptomatic hyperglycemia occurs after a long latency period, which reflects the large number of functioning $\beta$ cells that need to be destroyed before the clinical manifestation of the disease (2).

\section{Humoral immunity}

The disturbed immune response includes the humoral immunity arm too, producing autoantibodies that may precede the onset of clinical manifestation of T1DM for years. The main autoantibodies detected in patients with T1DM are those against GAD65, tyrosyl phosphatase (IA-2), insulin (IAA) and zinc transporter (ZnT8) (1). Studies in mice with early presentation of these autoantibodies suggest that proinsulin is the potential primary target. The great importance of insulin as an autoantigen is confirmed by the fact that deletion of its gene in mice greatly affects disease progression, while its administration during the pre-diabetic phase can prevent or delay the clinical expression of T1DM $(63,64)$. Another important autoantigen is the GAD enzyme, which is present in $\beta$ cells, as well as in the central nervous system and the testes (65). Anti-GAD autoantibodies are found in approximately $70 \%$ of the patients with T1DM at the time of diagnosis. IA-2 is also an important autoantigen, with approximately $60 \%$ of the patients with T1DM presenting positive autoantibodies at the time of diagnosis (66). Autoantibodies to IA-2 usually appear later than autoantibodies to insulin and GAD and are largely related to the progression of the disease. The zinc transporter (ZnT8) has also been more recently identified as autoantigen for T1DM. Indeed, $60-80 \%$ of the newly diagnosed patients show positive ZnT8 autoantibodies. In children monitored from birth to T1DM development, it was observed that ZnT8 autoantibodies appear later than autoantibodies to insulin (67) and typically disappear very early after the clinical manifestation of the disease (68). A large Finnish cohort provided evidence that ZnT8 autoantibodies' concentrations are related to the age, the HLA genotype and the metabolic status at diagnosis, but they cannot significantly improve the detection of $\beta$ cell autoimmunity (69). One of the best markers of progression to clinical T1DM is the simultaneous expression of two or three autoantibodies from the above (70). Very recently, the TEDDY (the environmental determinants of diabetes in the young) study, a prospective cohort study funded by the National Institutes of Health with an aim to identify environmental causes of T1DM and including children that are in genetic risk followed from birth with regular blood sampling, examined individuals who had already developed two or more autoantibodies. They investigated important factors that can contribute to the very variable rate of progression to the disease among children who are already positive for autoantibodies. These data suggested that the risk of progression was not different among those with or without a family history of T1DM, and it was higher for female gender, when a few high-risk HLA-DR and HLA-DQ subtypes were present, while it was inversely related to the age of first appearance of positive autoantibodies (71).

\section{Conclusions}

T1DM is the result of the autoimmune destruction of $\beta$ cells of the endocrine pancreas, leading to insulin deficiency. The process of this autoimmune destruction occurs in genetically susceptible individuals following the contribution of one or more environmental factors and usually develops over several months or years, when patients are asymptomatic and euglycemic but present positive relevant autoantibodies. Symptomatic hyperglycemia and diabetes supervene after a long latency period, which reflects the large percentage of $\beta$ cells that need to be destroyed or dysfunctioned first before overt diabetes become evident.

\section{Declaration of interest}

The authors declare that there is no conflict of interest that could be perceived as prejudicing the impartiality of this review.

\section{Funding}

This work did not receive any specific grant from any funding agency in the public, commercial or not-for-profit sector.

\section{References}

1 Paschou SA, Petsiou A, Chatzigianni K, Tsatsoulis A \& Papadopoulos GK. Type 1 diabetes as an autoimmune disease: the evidence. Diabetologia 201457 1500-1501. (https://doi.org/10.1007/ s00125-014-3229-5)

2 Atkinson MA \& Maclaren NK. The pathogenesis of insulin-dependent diabetes mellitus. New England Journal of Medicine 19943311428. (https://doi.org/10.1056/NEJM199411243312107)

3 Beyan H, Riese H, Hawa MI, Beretta G, Davidson HW, Hutton JC, Burger H, Schlosser M, Snieder H, Boehm BO, et al. Glycotoxin and

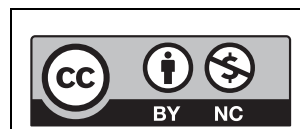

This work is licensed under a Creative Commons Attribution-NonCommercial 4.0 International License. 
autoantibodies are additive environmentally determined predictors of type 1 diabetes: a twin and population study. Diabetes 201261 1192-1198. (https://doi.org/10.2337/db11-0971)

4 Redondo MJ, Rewers M, Yu L, Garg S, Pilcher CC, Elliott RB \& Eisenbarth GS. Genetic determination of islet cell autoimmunity in monozygotic twin, dizygotic twin, and non-twin siblings of patients with type 1 diabetes: prospective twin study. BMJ 1999318698. (https://doi.org/10.1136/bmj.318.7185.698)

5 Størling J \& Pociot F. Type 1 diabetes candidate genes linked to pancreatic islet cell inflammation and beta-cell apoptosis. Genes 2017 8 E72.

6 Aly TA, Ide A, Jahromi MM, Barker JM, Fernando MS, Babu SR, Yu L, Miao D, Erlich HA, Fain PR, et al. Extreme genetic risk for type 1A diabetes. PNAS 2006103 14074. (https://doi.org/10.1073/ pnas.0606349103)

7 Klein J. The Major Histocompatibility Complex, Immunology, pp 270-309. New York, NY, USA: Wiley, 1982.

8 Janeway CA Jr, Travers P, Walport M \& Shlomchik MJ. Immunobiology, 6th ed. London, UK: Garland Science, 2005.

9 Khalil I, d'Auriol L, Gobet M, Morin L, Lepage V, Deschamps I, Park MS, Degos L, Galibert F \& Hors J. A combination of HLA-DQ beta Asp57-negative and HLA DQ alpha Arg52 confers susceptibility to insulin-dependent diabetes mellitus. Journal of Clinical Investigation 199085 1315. (https://doi.org/10.1172/JCI114569)

10 Rowe RE, Leech NJ, Nepom GT \& McCulloch DK. High genetic risk for IDDM in the Pacific Northwest. First report from the Washington State Diabetes Prediction Study. Diabetes 19944387.

11 Undlien DE, Friede T, Rammensee HG, Joner G, Dahl-Jørgensen K, Søvik O, Akselsen HE, Knutsen I, Rønningen KS \& Thorsby E. HLAencoded genetic predisposition in IDDM: DR4 subtypes may be associated with different degrees of protection. Diabetes 199746143. (https://doi.org/10.2337/diab.46.1.143)

12 Baschal EE, Aly TA, Babu SR, Fernando MS, Yu L, Miao D, Barriga KJ, Norris JM, Noble JA, Erlich HA, et al. HLA-DPB $1{ }^{*} 0402$ protects against type $1 \mathrm{~A}$ diabetes autoimmunity in the highest risk DR3DQB1*0201/DR4-DQB1*0302 DAISY population. Diabetes 200756 2405. (https://doi.org/10.2337/db07-0029)

13 Pugliese A, Gianani R, Moromisato R, Awdeh ZL, Alper CA, Erlich HA, Jackson RA \& Eisenbarth GS. HLA-DQB1*0602 is associated with dominant protection from diabetes even among islet cell antibody-positive first-degree relatives of patients with IDDM. Diabetes 199544 608. (https://doi.org/10.2337/diab.44.6.608)

14 Eisenbarth GS \& Gottlieb PA. Autoimmune polyendocrine syndromes. New England Journal of Medicine 2004350 2068-2079. (https://doi.org/10.1056/NEJMra030158)

15 Mein CA, Esposito L, Dunn MG, Johnson GC, Timms AE, Goy JV, Smith AN, Sebag-Montefiore L, Merriman ME, Wilson AJ, et al. A search for type 1 diabetes susceptibility genes in family from the United Kingdom. Nature Genetics 199819 297-300 (https://doi.org/10.1038/991)

16 Barratt BJ, Payne F, Lowe CE, Hermann R, Healy BC, Harold D, Concannon P, Gharani N, McCarthy MI, Olavesen MG, et al. Remapping the insulin gene/IDDM2 locus in type 1 diabetes. Diabetes 2004531884.

17 Anjos S \& Polychronakos C. Mechanisms of genetic susceptibility to type 1 diabetes: beyond HLA. Molecular Genetics and Metabolism 2004 81 187-195. (https://doi.org/10.1016/j.ymgme.2003.11.010)

18 Kavvoura FK \& Ioannidis JP. CTLA-4 gene polymorphisms and susceptibility to type 1 diabetes mellitus: a HuGE Review and metaanalysis. American Journal of Epidemiology 2005162 3. (https://doi. org/10.1093/aje/kwi165)

19 Smyth D, Cooper JD, Collins JE, Heward JM, Franklyn JA, Howson JM, Vella A, Nutland S, Rance HE, Maier L, et al. Replication of an association between the lymphoid tyrosine phosphatase locus (LYP/PTPN22) with type 1 diabetes, and evidence for its role as a general autoimmunity locus. Diabetes 2004533020.
20 Zheng W \& She JX. Genetic association between a lymphoid tyrosine phosphatase (PTPN22) and type 1 diabetes. Diabetes 200554 906-908. (https://doi.org/10.2337/diabetes.54.3.906)

21 Sabater L, Ferrer-Francesch X, Sospedra M, Caro P, Juan M \& Pujol-Borrell R. Insulin alleles and autoimmune regulator (AIRE) gene expression both influence insulin expression in the thymus. Journal of Autoimmunity 200525 312. (https://doi.org/10.1016/j. jaut.2005.08.006)

22 DeVoss JJ \& Anderson MS. Lessons on immune tolerance from the monogenic disease APS1. Current Opinion in Genetics and Development 200717 193. (https://doi.org/10.1016/j.gde.2007.04.001)

23 Wildin RS \& Freitas A. IPEX and FOXP3: clinical and research perspectives. Journal of Autoimmunity 200525 (Supplement) 56-62.

24 Paschou SA, Tigas S, Naka K, Papadopoulos GK \& Tsatsoulis A. The role of T regulatory cells (Tregs) in the development and prevention of type 1 diabetes. Journal of Clinical and Cellular Immunology 2012 S2 003. (https://doi.org/10.4172/2155-9899.S2-003)

25 Flanagan SE, Haapaniemi E, Russell MA, Caswell R, Lango Allen H, De Franco E, McDonald TJ, Rajala H, Ramelius A, Barton J, et al. Activating germline mutations in STAT3 cause early-onset multiorgan autoimmune disease. Nature Genetics 201446 812. (https://doi. org/10.1038/ng.3040)

26 Nejentsev S, Walker N, Riches D, Egholm M \& Todd JA. Rare variants of IFIH1, a gene implicated in antiviral responses, protect against type 1 diabetes. Science 2009324 387-389. (https://doi.org/10.1126/ science.1167728)

27 Downes K, Pekalski M, Angus KL, Hardy M, Nutland S, Smyth DJ, Walker NM, Wallace C \& Todd JA. Reduced expression of IFIH1 is protective for type 1 diabetes. PLOS ONE 20105 e12646. (https://doi. org/10.1371/journal.pone.0012646)

28 Huang K, Yanai A, Kang R, Arstikaitis P, Singaraja RR, Metzler M, Mullard A, Haigh B, Gauthier-Campbell C, Gutekunst CA, et al. Huntingtin-interacting protein HIP14 is a palmitoyl transferase involved in palmitoylation and trafficking of multiple neuronal proteins. Neuron 200444 977-986. (https://doi.org/10.1016/j. neuron.2004.11.027)

29 Berchtold LA, Størling ZM, Ortis F, Lage K, Bang-Berthelsen C, Bergholdt R, Hald J, Brorsson CA, Eizirik DL, Pociot F, et al. Huntingtin-interacting protein 14 is a type 1 diabetes candidate protein regulating insulin secretion and beta-cell apoptosis. PNAS 2011108 E681-E688. (https://doi.org/10.1073/pnas.1104384108)

30 Kaur S, Mirza AH, Brorsson CA, Fløyel T, Størling J, Mortensen HB, Pociot F \& Hvidoere International Study Group. The genetic and regulatory architecture of ERBB3-type 1 diabetes susceptibility locus. Molecular and Cellular Endocrinology 2016419 83-91. (https://doi. org/10.1016/j.mce.2015.10.002)

31 Menser MA, Forrest JM \& Bransby RD. Rubella infection and diabetes mellitus. Lancet 19781 57. (https://doi.org/10.1016/S01406736(78)90001-6)

32 Hober D \& Sauter P. Pathogenesis of type 1 diabetes mellitus: interplay between enterovirus and host. Nature Reviews Endocrinology 20106 279-289. (https://doi.org/10.1038/nrendo.2010.27)

33 Hober D \& Alidjinou EK. Enteroviral pathogenesis of type 1 diabetes: queries and answers. Current Opinion in Infectious Diseases 201326 263-269. (https://doi.org/10.1097/QCO.0b013e3283608300)

34 Szopa TM, Titchener PA, Portwood ND \& Taylor KW. Diabetes mellitus due to viruses - some recent developments. Diabetologia 199336 687. (https://doi.org/10.1007/BF00401138)

35 Yoon JW, Austin M, Onodera T \& Notkins AL. Isolation of a virus from the pancreas of a child with diabetic ketoacidosis. New England Journal of Medicine 1979300 1173. (https://doi.org/10.1056/ NEJM197905243002102)

36 Dotta F, Censini S, van Halteren AG, Marselli L, Masini M, Dionisi S, Mosca F, Boggi U, Muda AO, Del Prato S, et al. Coxsackie B4 virus infection of beta cells and natural killer cell insulitis in recent- http://www.endocrineconnections.org https://doi.org/10.1530/EC-17-0347
() 2018 The authors

Published by Bioscientifica Ltd

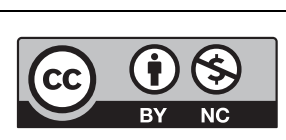

This work is licensed under a Creative Commons Attribution-NonCommercial 4.0 International License. 
onset type 1 diabetic patients. PNAS 2007104 5115. (https://doi. org/10.1073/pnas.0700442104)

37 Schloot NC, Willemen SJ, Duinkerken G, Drijfhout JW, de Vries RR \& Roep BO. Molecular mimicry in type 1 diabetes mellitus revisited: T-cell clones to GAD65 peptides with sequence homology to Coxsackie or proinsulin peptides do not crossreact with homologous counterpart. Human Immunology 200162 299-309. (https://doi. org/10.1016/S0198-8859(01)00223-3)

38 Horwitz MS, Bradley LM, Harbertson J, Krahl T, Lee J \& Sarvetnick N. Diabetes induced by Coxsackie virus: initiation by bystander damage and not molecular mimicry. Nature Medicine 19984 781-785. (https://doi.org/10.1038/nm0798-781)

39 Jaïdane H, Sauter P, Sane F, Goffard A, Gharbi J \& Hober D. Enteroviruses and type 1 diabetes: towards a better understanding of the relationship. Reviews in Medical Virology 201020 265-280.

40 Hviid A, Stellfeld M, Wohlfahrt J \& Melbye M. Childhood vaccination and type 1 diabetes. New England Journal of Medicine 2004 350 1398. (https://doi.org/10.1056/NEJMoa032665)

41 Virtanen SM, Saukkonen T, Savilahti E, Ylönen K, Räsänen L, Aro A, Knip M, Tuomilehto J \& Akerblom HK. Diet, cow's milk protein antibodies and the risk of IDDM in Finnish children. Childhood Diabetes in Finland Study Group. Diabetologia 199437381.

42 Karges W, Pietropaolo M, CAckerley CA \& Dosch HM. Gene expression of islet cell antigen p69 in human ,mouse, and rat. Diabetes 199645 513-521. (https://doi.org/10.2337/diab.45.4.513)

43 Karlsson MG \& Ludvigsson J. The ABBOS-peptide from bovine serum albumin causes an IFN-gamma and IL-4 mRNA response in lymphocytes from children with recent onset of type 1 diabetes. Diabetes Research and Clinical Practice 200047 199-207. (https://doi. org/10.1016/S0168-8227(99)00127-8)

44 Norris JM, Barriga K, Klingensmith G, Hoffman M, Eisenbarth GS, Erlich HA \& Rewers M. Timing of initial cereal exposure in infancy and risk of islet autoimmunity. JAMA 2003290 1713. (https://doi. org/10.1001/jama.290.13.1713)

45 Parslow RC, McKinney PA, Law GR, Staines A, Williams R \& Bodansky HJ. Incidence of childhood diabetes mellitus in Yorkshire, northern England, is associated with nitrate in drinking water: an ecological analysis. Diabetologia 199740 550. (https://doi. org/10.1007/s001250050714)

46 Norris JM, Yin X, Lamb MM, Barriga K, Seifert J, Hoffman M, Orton HD, Barón AE, Clare-Salzler M, Chase HP, et al. Omega-3 polyunsaturated fatty acid intake and islet autoimmunity in children at increased risk for type 1 diabetes. JAMA 20072981420. (https://doi.org/10.1001/jama.298.12.1420)

47 Raab J, Giannopoulou EZ, Schneider S, Warncke K, Krasmann M, Winkler C \& Ziegler AG. Prevalence of vitamin D deficiency in pre-type 1 diabetes and its association with disease progression. Diabetologia 201457 902-908. (https://doi.org/10.1007/s00125-0143181-4)

48 Altieri B, Muscogiuri G, Barrea L, Mathieu C, Vallone CV, Mascitelli L, Bizzaro G, Altieri VM, Tirabassi G, Balercia G, et al. Does vitamin D play a role in autoimmune endocrine disorders? A proof of concept. Reviews in Endocrine and Metabolic Disorders 201718 335-346. (https://doi.org/10.1007/s11154-016-9405-9)

49 Dong JY, Zhang WG, Chen JJ, Zhang ZL, Han SF \& Qin LQ. Vitamin $\mathrm{D}$ intake and risk of type 1 diabetes: a meta-analysis of observational studies. Nutrients 20135 3551-3562. (https://doi.org/10.3390/ nu5093551)

50 Nwosu BU \& Maranda L. The effects of vitamin D supplementation on hepatic dysfunction, vitamin D status, and glycemic control in children and adolescents with vitamin D deficiency and either type 1 or type 2 diabetes mellitus. PLoS ONE 20149 e99646. (https://doi. org/10.1371/journal.pone.0099646)

51 Mishra A, Dayal D, Sachdeva N \& Attri SV. Effect of 6-months' vitamin $\mathrm{D}$ supplementation on residual beta cell function in children with type 1 diabetes: a case control interventional study. Journal of Pediatric Endocrinology and Metabolism 201629 395-400.

52 Beyan H, Wen L \& Leslie RD. Guts, germs, and meals: the origin of type 1 diabetes. Current Diabetes Reports 201212 456-462. (https://doi.org/10.1007/s11892-012-0298-z)

$53 \mathrm{Hu}$ C, Wong FS \& Wen L. Type 1 diabetes and gut microbiota: friend or foe? Pharmacological Research 201598 9-15. (https://doi. org/10.1016/j.phrs.2015.02.006)

54 Stene LC \& Gale EA. The prenatal environment and type 1 diabetes. Diabetologia 201356 1888-1897. (https://doi.org/10.1007/s00125013-2929-6)

55 Bonifacio E, Warncke K, Winkler C, Wallner M \& Ziegler AG. Cesarean section and interferon-induced helicase gene polymorphisms combine to increase childhood type 1 diabetes risk. Diabetes 201160 3300-3306. (https://doi.org/10.2337/db11-0729)

56 Jaïdane H, Sané F, Hiar R, Goffard A, Gharbi J, Geenen V \& Hober D. Immunology in the clinic review series; focus on type 1 diabetes and viruses: enterovirus, thymus and type 1 diabetes pathogenesis. Clinical and Experimental Immunology 2012168 39-46.

57 Jaïdane H, Caloone D, Lobert PE, Sane F, Dardenne O, Naquet P, Gharbi J, Aouni M, Geenen V \& Hober D. Persistent infection of thymic epithelial cells with coxsackievirus B4 results in decreased expression of type 2 insulin-like growth factor. Journal of Virology 201286 11151-11162.

58 Paschou SA, Vartholomatos G, Dova L, Kolaitis N, Giotaki E, Tsatsoulis A \& Papadopoulos GK. Distinctive differences in the phenotypic characteristics of Tregs of newly diagnosed type 1 diabetics, long-standing patients, relatives and controls. Diabetologia 200851 (Supplement 1(S1-S588)) S238.

59 Paschou SA, Vartholomatos G, Kolaitis N, Papadopoulos G \& Tsatsoulis A. Quantitative and qualitative changes in $\mathrm{T}$ regulatory lymphocytes (Tregs) in newly-diagnosed patients with type 1 diabetes. Endocrine Abstracts 201022 P347. (available at: http://www. endocrine-abstracts.org/ea/0022/ea0022p347.htm)

60 Eizirik DL, Colli ML \& Ortis F. The role of inflammation in insulitis and beta-cell loss in type 1 diabetes. Nature Reviews Endocrinology 20095 219-226. (https://doi.org/10.1038/nrendo.2009.21)

61 Cunha DA, Igoillo-Esteve M, Gurzov EN, Germano CM, Naamane N, Marhfour I, Fukaya M, Vanderwinden JM, Gysemans C, Mathieu C, et al. Death protein 5 and p53-upregulated modulator of apoptosis mediate the endoplasmic reticulum stress-mitochondrial dialog triggering lipotoxic rodent and human $\beta$-cell apoptosis. Diabetes 2012 $612763-2775$. (https://doi.org/10.2337/db12-0123)

62 Grieco FA, Sebastiani G, Juan-Mateu J, Villate O, Marroqui L, Ladrière L, Tugay K, Regazzi R, Bugliani M, Marchetti P, et al. MicroRNAs miR-23a-3p, miR-23b-3p, and miR-149-5p regulate the expression of proapoptotic BH3-only proteins DP5 and PUMA in human pancreatic $\beta$-cells. Diabetes 201766 100-112. (https://doi. org/10.2337/db16-0592)

63 Nakayama M, Abiru N, Moriyama H, Babaya N, Liu E, Miao D, Yu L, Wegmann DR, Hutton JC, Elliott JF, et al. Prime role for an insulin epitope in the development of type 1 diabetes in NOD mice. Nature 2005435220.

64 Krishnamurthy B, Dudek NL, McKenzie MD, Purcell AW, Brooks AG, Gellert S, Colman PG, Harrison LC, Lew AM, Thomas HE, et al. Responses against islet antigens in NOD mice are prevented by tolerance to proinsulin but not IGRP. Journal of Clinical Investigation 2006116 3258. (https://doi.org/10.1172/JCI29602)

65 Baekkeskov S, Aanstoot HJ, Christgau S, Reetz A, Solimena M, Cascalho M, Folli F, Richter-Olesen H \& De Camilli P. Identification of the $64 \mathrm{~K}$ autoantigen in insulin-dependent diabetes as the GABAsynthesizing enzyme glutamic acid decarboxylase. Nature $1990 \mathbf{3 4 7}$ 151. (https://doi.org/10.1038/347151a0)

66 Ellis TM, Schatz DA, Ottendorfer EW, Lan MS, Wasserfall C, Salisbury PJ, She JX, Notkins AL, Maclaren NK \& Atkinson MA. http://www.endocrineconnections.org https://doi.org/10.1530/EC-17-0347
() 2018 The authors Published by Bioscientifica Ltd

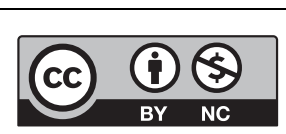

This work is licensed under a Creative Commons Attribution-NonCommercial 4.0 International License. 
The relationship between humoral and cellular immunity to IA-2 in IDDM. Diabetes 199847 566. (https://doi.org/10.2337/ diabetes.47.4.566)

67 Wenzlau JM, Juhl K, Yu L, Moua O, Sarkar SA, Gottlieb P, Rewers M, Eisenbarth GS, Jensen J, Davidson HW, et al. The cation efflux transporter ZnT8 (Slc30A8) is a major autoantigen in human type 1 diabetes. PNAS 2007104 17040. (https://doi.org/10.1073/ pnas.0705894104)

68 Wenzlau JM, Walter M, Gardner TJ, Frisch LM, Yu L, Eisenbarth GS, Ziegler AG, Davidson HW \& Hutton JC. Kinetics of the post-onset decline in zinc transporter 8 autoantibodies in type 1 diabetic human subjects. Journal of Clinical Endocrinology and Metabolism 2010 95 4712. (https://doi.org/10.1210/jc.2010-0169)

69 Salonen KM, Ryhänen S, Härkönen T, Ilonen J, Knip M \& Finnish Pediatric Diabetes Register. Autoantibodies against zinc transporter
8 are related to age, metabolic state and HLA DR genotype in children with newly diagnosed type 1 diabetes. Diabetes/Metabolism Research and Reviews 201329 646-654. (https://doi.org/10.1002/ dmrr.2440)

70 Verge CF, Gianani R, Kawasaki E, Yu L, Pietropaolo M, Jackson RA, Chase HP \& Eisenbarth GS. Prediction of type I diabetes in first-degree relatives using a combination of insulin, GAD, and ICA512bdc/IA-2 autoantibodies. Diabetes 199645 926. (https://doi. org/10.2337/diab.45.7.926)

71 Krischer JP, Liu X, Lernmark Å, Hagopian WA, Rewers MJ, She JX, Toppari J, Ziegler AG, Akolkar B \& TEDDY Study Group. The influence of type 1 diabetes genetic susceptibility regions, age, sex, and family history to the progression from multiple autoantibodies to type 1 diabetes: a TEDDY Study Report. Diabetes 201766 3122-3129. (https://doi.org/10.2337/db17-0261)

Received in final form 15 November 2017

Accepted 30 November 2017

Accepted Preprint published online 30 November 2017 http://www.endocrineconnections.org https://doi.org/10.1530/EC-17-0347
(C) 2018 The authors Published by Bioscientifica Ltd

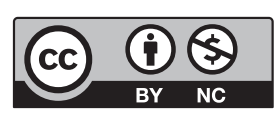

This work is licensed under a Creative Commons Attribution-NonCommercial 4.0 International License. 